\title{
Prevalence of Antibodies to Leishmania infantum and Trypanosoma cruzi in Wild Canids From South Carolina
}

Author(s): Alexa C. Rosypal, Richard R. Tidwell, David S. Lindsay

Source: Journal of Parasitology, 93(4):955-957. 2007.

Published By: American Society of Parasitologists

DOI: http://dx.doi.org/10.1645/GE-1057R.1

URL: http://www.bioone.org/doi/full/10.1645/GE-1057R.1

BioOne (www.bioone.org) is a nonprofit, online aggregation of core research in the biological, ecological, and environmental sciences. BioOne provides a sustainable online platform for over 170 journals and books published by nonprofit societies, associations, museums, institutions, and presses.

Your use of this PDF, the BioOne Web site, and all posted and associated content indicates your acceptance of BioOne's Terms of Use, available at www.bioone.org/page/terms of use.

Usage of BioOne content is strictly limited to personal, educational, and non-commercial use. Commercial inquiries or rights and permissions requests should be directed to the individual publisher as copyright holder. 

Leishmania infantum and Trypanosoma cruzi in Wild Canids From South Carolina," Journal of Parasitology, Vol. 93, No. 4, pp. 955-957. doi: http://dx.doi.org/10.1645/GE-1057R.1

findings and conclusions in this report are those of the authors and do not necessarily represent the views of the funding agency.

\section{LITERATURE CITED}

Cully, J. F., JR., L. G. Carter, And K. L. Gage. 2000. New records of sylvatic plague in Kansas. Journal of Wildlife Diseases 36: 389392.

Dumler, J. S., A. F. Barbet, C. P. J. Bekker, G. A. Dasch, G. H. Palmer, S. C. Ray, Y. Rikinisa, and F. R. RuRangirwa. 2001. Reorganization of genera in the families Rickettsiaceae and Anaplasmataceae in the order Rickettsiales: unification of some species of Ehrlichia with Anaplasma, Cowdria with Ehrlichia and Ehrlichia with Neorickettsia, descriptions of six new species combinations and designation of Ehrlichia equi and 'HGE agent' as subjective synonyms of Ehrlichia phagocytophila. International Journal of Systematics, Evolution and Microbiology 51: 2145-2165.

Hounamdi, L., P.-E. Fournier, R. Fang, H. Lepidi, and D. Raoult. 2002. An experimental model of human body louse infection with Rickettsia prowazekii. Journal of Infectious Diseases 186: 1639_ 1646.

Houpikian, P., AND D. Raoult. 2001. 16S/23S rRNA intergenic spacer regions for phylogenetic analysis, identification, and subtyping of Bartonella species. Journal of Clinical Microbiology 39: 27682778 .

Hubbard, C. A. 1947. Fleas of western North America: Their relation to public health. Hafner, New York, New York, 533 p.

Ishikura, M., S. Ando, Y. Shinagawa, K. Matsuura, S. Hasegawa, T. Nakayama, H. Fujta, and M. Watanabe. 2003. Phylogenetic analysis of spotted fever group rickettsiae based on gltA, 17-kDa, and rOmpA genes amplified by nested PCR from ticks in Japan. Microbiology and Immunology 47: 823-832.

Kosoy, M., M. Murray, R. D. Gilmore, JR., Y. Bai, and K. L. Gage. 2003. Bartonella strains from ground squirrels are identical to Bar- tonella washoensis isolated from a human patient. Journal of Clinical Microbiology 41: 645-650.

LEwIS, R. E. 2002. A review of the North American species of Oropsylla Wagner and Ioff, 1926 (Siphonaptera: Ceratophyllidae: Ceratophyllinae). Journal of Vector Ecology 27: 184-206.

Parola, P., S. Shpynov, M. Montoya, M. Lopez, P. Houpikian, Z. Zeaiter, H. Guerra, AND D. RaOult. 2002. First molecular evidence of new Bartonella spp. in fleas and a tick from Peru. American Journal of Tropical Medicine and Hygiene 67: 135-136.

Phongmany, S., J. Rolain, R. Phetsouvanh, S. D. Blacksell, V. Soukkhaseum, B. Rasachack, K. Phiasakha, S. Soukkhaseum, K. FriChithavong, V. ChU, ET AL. 2006. Rickettsial infections and fever, Vientiane, Laos. Emerging Infectious Diseases 12: 256-262.

Reed, W. P., D. L. Palmer, R. C. Williams, JR., AND A. L. Kisch. 1970. Bubonic plague in the southwestern United States. A review of recent experience. Medicine 49: 465-486.

Reeves, W. K., A. D. Loftis, J. A. Gore, And G. A. Dasch. 2005. Molecular evidence for novel Bartonella spp. in Trichobius major (Diptera: Streblidae) and Cimex adjunctus (Hemiptera: Cimicidae) from two southeastern bat caves, U.S.A. Journal of Vector Ecology 30: $339-341$.

Stark, H. E. 1970. A revision of the flea genus Thrassis Jordan 1933 (Siphonaptera: Ceratophyllidae) with observations on ecology and relationship to plague. University of California Publication in Entomology 53: 1-184.

Stevenson, H. L., M. B. Labruna, J. A. Montenieri, M. Y. Kosoy, K. L. Gage, AND D. H. Walker. 2005. Detection of Rickettsia felis in a New World flea species, Anomiopsyllus nudata (Siphonaptera: Ctenophthalmidae). Journal of Medical Entomology 42: 163-167.

, Y. Bai, M. Y. Kosoy, J. A. Montenieri, J. L. Lowell, M. C. Chu, AND K. L. Gage. 2003. Detection of novel Bartonella strains and Yersinia pestis in prairie dogs and their fleas (Siphonaptera: Ceratophyllidae and Pulicidae) using multiplex polymerase chain reaction. Journal of Medical Entomology 40: 329-337.

\title{
Prevalence of Antibodies to Leishmania infantum and Trypanosoma cruzi in Wild Canids From South Carolina
}

\begin{abstract}
Alexa C. Rosypal, Richard R. Tidwell, and David S. Lindsay${ }^{\star}$, Department of Pathology and Laboratory Medicine, School of Medicine, University of North Carolina at Chapel Hill, Chapel Hill, North Carolina 27599-7525; *Center for Molecular Medicine and Infectious Diseases, Department of Biomedical Sciences and Pathobiology, Virginia-Maryland Regional College of Veterinary Medicine, Virginia Tech, Blacksburg, Virginia 24061-0342; †To whom correspondence should be addressed. e-mail: lindsayd@vt.edu
\end{abstract}

ABSTRACT: Wild canids are reservoir hosts for Leishmania infantum and Trypanosoma cruzi. The present study examined the prevalence of antibodies to these zoonotic parasites in a population of wild canids from a nonagricultural setting in South Carolina. Sera from 26 gray foxes (Urocyon cinereoargenteus) and 2 coyotes (Canis latrans) were examined for antibodies to $L$. infantum and $T$. cruzi using the indirect immunofluorescent antibody test and commercially available parasitespecific immunochromatigraphic strip assays. Antibodies to $L$. infantum were not detected by either assay in gray foxes or coyotes. Two $(8 \%)$ of 26 gray foxes were positive in both the $T$. cruzi immunofluorescent antibody and strip assays. Antibodies to T. cruzi were not detected in coyotes. Results from this study indicate that wild canids are exposed to $T$. cruzi, but not $L$. infantum. in this geographic region.

Leishmania infantum and Trypanosoma cruzi are zoonotic parasites and both are endemic in the United States. Leishmaniasis and Chagas' disease caused by infection with $L$. infantum and $T$. cruzi, respectively, are potentially fatal diseases in both dogs and humans. Canine leishmaniasis caused by $L$. infantum is recognized as an important disease in the North American foxhound population, and T. cruzi-infected foxhounds also have been described (Duprey et al., 2006)
A sylvatic cycle of $T$. cruzi exists that involves parasite transmission between reduviid bugs and wildlife reservoir hosts. Little data are available, however, regarding $L$. infantum and T. cruzi infections in wild canids in the United States. The present study was conducted to determine the seroprevalence of antibodies to $L$. infantum and T. cruzi in a population of gray foxes (Urocyon cinereoargenteus) and coyotes ( $\mathrm{Ca}$ nis latrans) from South Carolina.

Sera from 26 gray foxes (Lindsay et al., 2001) and 2 coyotes from South Carolina were examined for antibodies to $L$. infantum and $T$. cruzi. The wild canids examined in the present study originated from a nonagricultural setting in Aiken and Barnwell counties on the Department of Energy's Savannah River site. Other wildlife species are present in the study area, including white-tailed deer (Odocoileus virginianus), and they are hunted with domestic dogs only during hunting season; otherwise, domestic dogs are not allowed in the study location. The animals were collected alive in padded leg-hold traps and sedated using intramuscular injections of ketamine and xylazine. Animals were bled while unconscious. After venipuncture, animals were humanely killed for other studies on the population of wild canids in this study site. The age of each fox was determined using tooth cementum analysis of an extracted lower premolar. Ages of coyotes were not available. Sera were 
examined by the quantitative indirect fluorescent antibody test (IFAT) and commercially available immunochromatographic dipstick assays for qualitative antibody detection.

The IFAT was used to examine sera for $\operatorname{IgG}$ antibodies to $T$. cruzi and L. infantum as described previously (Dubey et al., 2005; Rosypal et al., 2005). Briefly, sera were initially screened at a 1:25 dilution in phosphate-buffered saline (PBS). Positive samples were examined at doubling dilutions and titrated to a final dilution of $1: 12,800$. In the $T$. cruzi IFAT, Brazil strain amastigotes and trypomastigotes were washed in PBS, and approximately 40,000 parasites per well were air-dried on 12-well microscope slides. Parasite antigen was affixed on IFAT slides with acetone. Sera $(30 \mu \mathrm{l} /$ well $)$ were diluted to 1:25 in PBS and incubated on the slides for $30 \mathrm{~min}$ at room temperature in a humidified box. Slides were washed 2 times for $5 \mathrm{~min}$ in PBS. The secondary antibody used in the present study was fluorescein isothiocyanate-conjugated goat anti-dog IgG $(\mathrm{H}+\mathrm{L})$ (Kirkegaard and Perry Laboratories, Gaithersburg, Maryland). Fluorescent conjugate $(30 \mu \mathrm{l} /$ well) at a dilution of 1:10 in PBS-Evans blue solution was incubated on the slides for $30 \mathrm{~min}$ at room temperature in a humidified box. Slides were washed twice for $5 \mathrm{~min}$ in PBS, mounted in Fluoromount-G (Southern Biotechnology Associates Inc., Birmingham, Alabama), and covered with coverslips (24 $\times$ $60 \mathrm{~mm}$ ). Slides were viewed with an Olympus BX60 epifluorescent microscope equipped with differential contrast optics. The procedure was the same as described above for the Leishmania IFAT, except 50,000 promastigotes of L. infantum (ATCC PRA-149) (canine isolate from a naturally infected Virginia foxhound; Rosypal, Troy, Zajac et al., 2003) per well were used as antigen. Canine control sera were used on each IFAT slide. Sera from dogs with proven $T$. cruzi and L. infantum infections were used as positive controls for respective IFAT tests. Negative control sera used in both IFATs was obtained from a dog proven to be uninfected by both culture and serology.

Sera also were tested qualitatively by commercially available canine immunochromatographic dipstick assays according to the manufacturer's test procedure. The tests are based on recombinant antigens that previous reports have demonstrated superior performance over traditional serological screening tests based on crude antigens or whole organisms (Houghton et al., 2000; Scalone et al., 2002). Canine sera were tested for anti-recombinant K39 (rK39) (Kalazar Detect ${ }^{\text {TW }}$ Canine Rapid Test; InBios International Ltd., Seattle, Washington), which is an amas tigote protein specific to visceralizing Leishmania spp., and it does not crossreact T. cruzi (Burns et al., 1993). Anti-T. cruzi antibodies were evaluated by a dipstick assay (Trypanosoma Detect ${ }^{\mathrm{TM}}$ MRA Rapid Test; InBios International Ltd.) based on multiepitope recombinant antigens The IFAT was considered the "gold standard" for comparisons of sensitivity and specificity, because it has been shown to have a high sensitivity for detecting antibodies to T. cruzi in wildlife (Yabsley et al., 2001).

Positive $T$. cruzi IFAT and $T$. cruzi dipstick assay results were found in $2(8 \%)$ of 26 gray foxes. One 5-yr-old male fox from Aiken County and 17 -yr-old female fox from Barnwell County were both IFAT positive at a final titer of 1:25. None of the coyotes had antibodies to $T$. cruzi by either IFAT or dipstick tests. None of the wild canids tested in the present study had evidence of antibodies to L. infantum by either serological assay. The sensitivity and specificity of the dipstick assays were $100 \%$ compared with IFAT as the gold standard.

Leishmania infantum and T. cruzi are endemic parasites in the United States and Canada (Rosypal, Zajac, and Lindsay, 2003; Rosypal et al., 2005; Duprey et al., 2006). Autochthonous canine leishmaniasis caused by $L$. infantum is well recognized in the North American foxhound population, and Leishmania sp.-infected and T. cruzi-infected foxhounds have been detected in South Carolina (Duprey et al., 2006). The lack of antibodies to L. infantum in wild canids examined in this study is in agreement with previous findings (Duprey et al., 2006). Serologica surveys conducted by the Centers for Disease Control and Prevention indicated that 2 of $291(0.7 \%)$ wild canid samples collected in the southeastern United States had antibodies to $T$. cruzi, although both the exact collection location and wild canine species were unclear (Duprey et al. 2006).

Trypanosoma cruzi infection has been described in a variety of wild animals in the southeastern United States (John and Hoppe, 1986; Pung et al., 1995). Seropositive raccoons have been reported from both urban (Hancock et al., 2005) and nonurban (Yabsley et al., 2002a, 2002b) areas in the United States, including South Carolina. In contrast to our study, 19 of $134(14.2 \%)$ seropositive coyotes were detected in Texas (Grögl et al., 1984), although only 2 coyotes were tested in the present work. McKeever et al. (1958) isolated T. cruzi-like parasites from 2 of $118(1.7 \%)$ gray foxes collected in southwestern Georgia and northwestern Florida. Our report, however, is apparently the first to document antibodies to $T$. cruzi in gray foxes from South Carolina.

The immunochromatigraphic strip assays used in this study are commercially available for domestic dogs, but they have not been validated using wild canine serum. The strip tests are qualitative, and the intensity of the chromagen in the test region varies depends on the concentration of antibodies present in the sample. According to the manufacturer, a faint line should be considered a positive result. The positive $T$. cruzi strip assays in 2 gray foxes in the current study had positive IFAT results at a concentration of 1:25. We compared results of the dipstick assays to IFAT, and we found $100 \%$ sensitivity and specificity compared with the gold standard. To our knowledge, this is the first serological study using the Leishamania sp. and T. cruzi dipstick assays in wild canids. Dipstick assays are simple, rapid tests that are easier to perform than IFAT. Results from this work indicate that these tests warrant further study with additional gray fox samples and possibly other wild canine species to validate their usefulness as a serological screening tool in wild canids.

We thank J. S. Weston, Savannah River Ecology Laboratory, and S. E. Little, Center for Veterinary Health Sciences, Oklahoma State University, for providing gray fox and coyote sera used in this study. We are grateful to Stephen Barr from the College of Veterinary Medicine Cornell University, for providing $T$. cruzi-positive dog sera. The contribution of R.R.T. was supported by a grant from the Bill and Melinda Gates Foundation, and the contribution of A.C.R. was supported by the National Institute of General Medical Sciences GM-00678. A.C.R. is a fellow with the Seeding Postdoctoral Innovators in Research and Education (SPIRE) postdoctoral training program.

\section{LITERATURE CITED}

Burns, J. M., Jr., W. G. Shreffler, D. R. Benson, H. W. Ghalib, R. BADARO, AND S. G. SEED. 1993. Molecular characterization of a kinesin-related antigen of Leishmania chagasi that detects specific antibody in African and American visceral leishmaniasis. Proceedings of the National Academy of Sciences USA 90: 775-779.

Dubey, J. P., A. C. Rosypal, V. Pierce, S. N. Scheinberg, and D. S. LINDSAY. 2005. Placentitis associated with leishmaniasis in a dog. Journal of the Veterinary Medical Association 227: 1266-1269.

Duprey, Z. H., F. J. Steurer, J. A. Rooney, L. V. Kirchoff, J. E. JaCkson, E. D. Rowton, And P. M. Schantz. 2006. Canine visceral leishmaniasis: United States and Canada, 2000-2003. Emerging Infectious Diseases 12: 440-446.

Grögl, M., R. E. Kuhn, D. S. Davis, and G. E. Green. 1984. Antibodies to Trypanosoma cruzi in coyotes in Texas. Journal of Parasitology 70: 189-191.

Hancock, K., A. M. Zajac, O. J. Pung, F. Elvinger, A. C. Rosypal, AND D. S. LindSAY. 2005. Prevalence of antibodies to Trypanosoma cruzi in raccoons (Procyon lotor) from an urban area of northern Virginia. Journal of Parasitology 91: 470-472.

Houghton, R. L., D. R. Benson, L. D. Reynolds, P. D. McNeill, P. R. Sleath, M. J. Lodes, Y. A. Skeiky, R. Badaro, A. U. Krettli, AND S. G. REED. 2000. Multiepitope synthetic peptide and recombinant protein for the detection of antibodies to Trypanosoma cruzi in patients with treated or untreated Chagas' disease. Journal of Infectious Diseases 181: 325-330.

John, D. T., AND K. L. Hoppe. 1986. Trypanosoma cruzi in wild raccoons in Oklahoma. American Journal of Veterinary Research 47: 1056-1059.

Lindsay, D. S., J. L. Weston, And S. E. Little. 2001. Prevalence of antibodies to Neospora caninum and Toxoplasma gondii in gray foxes (Urocyon cinereoargenteus) from South Carolina. Veterinary Parasitology 97: 159-164.

McKeever, S. G., G. W. Gorman, and L. Norman. 1958. Occurrence of Trypanosoma cruzi-like organism in some mammals from southwestern Georgia and northwestern Florida. Journal of Parasitology 44: 583-587.

Pung, O. J., C. W. Banks, D. N. Jones, And M. W. Krissinger. 1995. Trypanosoma cruzi in wild raccoons, opossums, and triatomine 
bugs in southeast Georgia, U.S.A. Journal of Parasitology 81: 324 326.

Rosypal, A. C., G. C. Troy, R. B. Duncan, JR., A. M. Zajac, and D. S. LiNDSAY. 2005. Utility of diagnostic tests used in diagnosis on infection in dogs experimentally inoculated with a North American isolate of Leishmania infantum infantum. Journal of Veterinary Internal Medicine 19: 802-809.

$\longrightarrow$, A. M. Zajac, R. B. Duncan, JR. K. Waki, K. P. Chang, AND D. S. LindSAY. 2003. Emergence of zoonotic canine leishmaniasis in the United States: Isolation and immunohistochemical detection of Leishmania infantum from foxhounds from Virginia. Journal of Eukaryotic Microbiology 50: S691-S693.

Rosypal, A. C., A. M. ZaJAC, AND D. S. LindSAy. 2003. Canine visceral leishmaniasis and its emergence in the United States. Veterinary Clinics of North America Small Animal Practice 33: 921-937.
Scalone, A., R. Deluna, G. Oliva, L. Baldi, G. Satta, G. Vesco, W. Mignone, C. Turilli, R. R. Mondesire, D. Simpson, et al. 2002. Evaluation of the Leishmania recombinant K39 antigen as a diagnostic marker for canine leishmaniasis and validation of a standardized enzyme-linked immunosorbent assay. Veterinary Parasitology 104: 275-285.

Yablsey, M. J., AND G. P. Noblet. 2002a. Biological and molecular characterization of a raccoon isolate of Trypanosoma cruzi from South Carolina. Journal of Parasitology 88: 1273-1276.

- AND 2002b. Seroprevalence of Trypanosoma cruzi in raccoons from South Carolina and Georgia. Journal of Wildlife Diseases 38: 75-83.

- AND O. J. Pung. 2001. Comparison of serological methods and blood culture for detection of Trypanosoma cruzi infection in raccoons (Procyon lotor). Journal of Parasitology 87: $1155-1159$.

\title{
Distribution Pattern of Phthirapterans Infesting Certain Common Indian Birds
}

\author{
A. K. Saxena, Sandeep Kumar, Nidhi Gupta, J. D. Mitra, S. A. Ali, and Roshni Srivastava, Department of Zoology, Government Raza Post \\ Graduate College, Rampur (U.P.) 244 901, India. e-mail: akscsir@rediffmail.com
}

ABSTRACT: The prevalence and frequency distribution patterns of 10 phthirapteran species infesting house sparrows, Indian parakeets, common mynas, and white breasted kingfishers were recorded in the district of Rampur, India, during 2004-05. The sample mean abundances, mean intensities, range of infestations, variance to mean ratios, values of the exponent of the negative binomial distribution, and the indices of discrepancy were also computed. Frequency distribution patterns of all phthirapteran species were skewed, but the observed frequencies did not correspond to the negative binomial distribution. Thus, adult-nymph ratios varied in different species from 1:0.53 to 1:1.25. Sex ratios of different phthirapteran species ranged from 1:1.10 to 1:1.65 and were female biased.

Certain workers have provided useful information on the prevalence and frequency distribution pattern of Phthiraptera on selected avian hosts. Work done so far on the subject has been reviewed from time to time (Marshall, 1981; Price and Graham, 1997; Price et al., 2003). The patterns of abundance of different lice on their avian hosts have been further discussed by Rekasi et al. (1997), Rozsa (1997), and Reiczigel et al. (2005). Here, we report information on the prevalence and frequency distribution patterns of 10 different phthirapteran species para- sitizing some common Indian birds: house sparrow (Passer domesticus), Indian parakeet (Psittacula eupatria), common myna (Acridotheres tristis), and white-breasted kingfisher (Halcyon smyrnensis).

All birds were captured live (with mist nets) in the district of Rampur (U.P.), India, during 2004 and 2005. After tying the legs, each bird was thoroughly searched for the presence of lice by visual examination. Infested birds were then subjected to delousing by fumigation (modified "Fair-Isle" method). The efficacy of different methods for delousing infested birds has been discussed elsewhere (Clayton and Drown, 2001). Head and body feathers were further examined using a stereozoom trinocular microscope to remove the remaining lice. The entire louse load was placed in $70 \%$ alcohol and separated according to species, age, and gender. The prevalence $(\%)$, mean $(X)$, and variance $\left(s^{2}\right)$ were calculated. The exponent $(k)$ of negative binomial distribution and index of discrepancy $(D)$ (Rozsa et al., 2000) were generated, and the goodness of fit between observed and expected frequency distribution was determined by chi-square tests.

Three phthirapteran species, Brueelia subtilis (Nitzsch, 1874), Echinophilopterus chapini (Ewing, 1927), and Myrsidea quadrifasciata (Piaget, 1880), were recovered from 100 house sparrows (Table I). Frequency distribution patterns of the 3 species were skewed, but were not

TABLE I. Summary of distribution patterns of phthirapterans infesting of house sparrows, Indian parakeets, common myna, and white-breasted kingfishers in the district of Rampur, India, during 2004 and 2005.

\begin{tabular}{|c|c|c|c|c|c|c|c|c|c|}
\hline Host & $\begin{array}{c}\text { Sample } \\
\text { size }\end{array}$ & Louse species & $\begin{array}{c}\text { Prevalence } \\
(\%)\end{array}$ & $\begin{array}{c}\text { Sample } \\
\text { mean } \\
\text { abundance }\end{array}$ & $\begin{array}{l}\text { Range of } \\
\text { infestation }\end{array}$ & $\begin{array}{c}\text { Mean } \\
\text { intensity } \\
(X)\end{array}$ & $\begin{array}{l}\text { Variance } \\
\text { to mean } \\
\text { ratio }\left(s^{2}\right)\end{array}$ & $\begin{array}{c}\text { Exponent of } \\
\text { negative } \\
\text { binomial }(k)\end{array}$ & $\begin{array}{c}\text { Index of } \\
\text { discrepancy } \\
\text { (D) }\end{array}$ \\
\hline \multirow[t]{3}{*}{ House sparrow } & 100 & Brueelia subtilis & 31.0 & 4.1 & $1-41$ & 13.3 & 16.0 & 0.11 & 0.79 \\
\hline & 100 & Echinophilopterus chapini & 14.0 & 1.1 & $2-21$ & 7.6 & 10.6 & 0.05 & 0.90 \\
\hline & 100 & Myrsidea quadrifasciata & 20.0 & 1.5 & $2-28$ & 9.7 & 12.8 & 0.07 & 0.87 \\
\hline \multirow[t]{2}{*}{ Indian parakeet } & 100 & Neopsittaconirmus elbeli & 34.0 & 7.4 & $2-46$ & 21.8 & 21.2 & 0.11 & 0.76 \\
\hline & 100 & Echinophilopterus chapini & 17.0 & 13.8 & $1-28$ & 13.8 & 16.6 & 0.05 & 0.88 \\
\hline \multirow[t]{4}{*}{ Common myna } & 100 & Myrsidea invadens & 31.0 & 5.1 & $2-63$ & 16.3 & 32.1 & 0.10 & 0.86 \\
\hline & 100 & Menacanthus eurysternus & 13.0 & 2.3 & $2-32$ & 17.5 & 20.8 & 0.03 & 0.90 \\
\hline & 100 & Brueelia chayanh & 24.0 & 6.9 & $3-82$ & 28.9 & 41.9 & 0.06 & 0.86 \\
\hline & 100 & Sturnidoecus bannoo & 42.0 & 15.6 & $3-106$ & 37.07 & 50.3 & 0.12 & 0.78 \\
\hline \multicolumn{10}{|l|}{ White-breasted } \\
\hline kingfisher & 30 & Meropoecus sp. & 40.0 & 7.1 & $6-44$ & 17.75 & 20.09 & 0.15 & 0.71 \\
\hline
\end{tabular}

